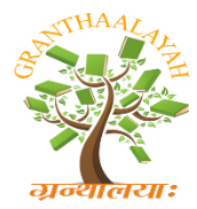

\author{
INTERNATIONAL JOURNAL OF RESEARCH \\ GRANTHAALAYAH \\ A knowledge Repository
}

Science

\title{
AYURVEDIC MANAGEMENT OF DUCHENNE MUSCULAR DYSTROPHY: A SHORT REVIEW
}

\author{
Dr. Akshay A Patankar *1, Dr. Renu B Rathi ${ }^{2}$ \\ ${ }^{* 1}$ M.D. Kaumarbhritya-Balrog (Ayurved), PG Scholar, Kaumarbhritya Department, Mahatma \\ Gandhi Ayurvedic Medical College \& Research Centre, Wardha India \\ ${ }^{2}$ M.D. Kaumarbhritya-Balrog (Ayurved), HOD and Professor, Kaumarbhritya Department, \\ Mahatma Gandhi Ayurvedic Medical College \& Research Centre, Wardha India
}

\begin{abstract}
Duchenne muscular dystrophy is a neuromuscular disorder characterized by deficient dystrophin protein in the muscle. The main symptoms the patient presented were delay in expressive and receptive language development, visual discontent, hyperkinetic behaviour, and inability to initiate and maintain social contact with peers. The data obtained from the family, following clinical examination, laboratory investigation results and assessment of mental status were significant for the diagnosis of Autism Spectrum Disorder, hyperkinetic behaviour and Duchenne Muscular Dystrophy.

In Ayurveda it has been classified under Medomamsa dusti further vitiates the Vata doshas occurs due to the Bheejabagahaavyava Dusti. In modern medicine there is no significant treatment available for this diseases while in Ayurvedic panchakrma therapy shows significant results in all signs and symptoms of this diseases.
\end{abstract}

Keywords: Duchenne Muscular Dystrophy (DMD); Developmental Disorders; Ayurvedic Management.

Cite This Article: Dr. Akshay A Patankar, and Dr. Renu B Rathi. (2019). "AYURVEDIC MANAGEMENT OF DUCHENNE MUSCULAR DYSTROPHY: A SHORT REVIEW." International Journal of Research - Granthaalayah, 7(1), 179-183. https://doi.org/10.29121/granthaalayah.v7.i1.2019.1046.

\section{Introduction}

Duchenne muscular dystrophy is a neuromuscular disorder. The estimated prevalence of Duchene muscular dystrophy was 1 in every 7,250 males aged 5-25 years. ${ }^{(1)}$ Duchene muscular dystrophy was characterized by motor impairments, difficulties in walking, waddling, toe walking, difficulties in climbing stairs, running or lifting off the ground. Para-clinically, an increase in serum creatinine level can be observed. In Ayurveda this pathogenesis occurs due to the Bheejabagahaavyava Dusti which leads to Vata Parkopa takes sthana samshraya in Mamsa and medo Dhatu vitiates and depletes them (x-linked progressive degenerative disorder of muscle 
tissue) ${ }^{(2)}$. Acharya Charaka has clearly mentioned about the close relation of both Mamsa and Medo Dhatu Viz. to Dhatukshayaj vata pathogenesis which in term degrades and causes the Dusti. (3)

\section{Duchenne Muscular Dystrophy}

\section{Definition}

Duchenne Muscular Dystrophy is caused by a change (mutation) of the gene that makes a protein called dystrophin. This protein is needed for muscle cells to keep their shape and work properly. An abnormal gene cannot make this protein and without it, muscle cells collapse and die. ${ }^{(4)} \mathrm{X}$ linked recessive mutation of the dystrophin gene that affects males almost exclusively. Progressive weakness in hip and shoulder girdle muscles beginning by age 5; by age 12, the majority were non-ambulatory in the era prior to the use of glucocorticoids. Survival beyond age 25 is rare. Associated problems include tendon and muscle contractures, progressive kyphoscoliosis, impaired pulmonary function, cardiomyopathy, and intellectual impairment. Palpable enlargement and firmness of some muscles ${ }^{(5)}$. The presence of cardiomyopathy can be considered a particular symptom in muscular dystrophy, so a neuromuscular evaluation is necessary in this case. It may be asymptomatic until the final stage of the disease. Scoliosis is a complication that develops especially after the loss of ambulation and should be regularly radiological assessed ${ }^{(6)}$.

\section{Sings and Symptomps of DMD}

The first symptoms of DMD usually appear between 2 to 5 years of age. Symptoms of DMD may include:

- Muscle weakness - The first muscles that are affected are those around the hips and upper thighs. Children may have difficulty walking, running, jumping, climbing stairs or standing up from the floor.

- Loss of muscle coordination - Children may seem unsteady, clumsy, fall often or "waddle" when they walk.

- Muscle size - As the muscles are damaged, the muscle is replaced by fat and connective tissue and can shrink (atrophy). The calf muscles often become larger (hypertrophy) and other muscles may be enlarged early on.

- Toe walking - The muscles become tight around joints, limiting movement. When walking becomes difficult, children may walk on their "tippy-toes" or balls of their feet.

- Learning disabilities - Some children have learning difficulties, which are usually not severe and usually do not get worse. DMD is a progressive disorder, meaning the muscles get weaker over time. The muscle weakness spreads and begins to affect the ability to walk. Later on, muscles of the heart and those around the lungs become affected.

\section{Examination of the Child}

Reviewing the results of the following tests -

- Blood tests - CK level - Muscles that are weak or damaged leak an enzyme called CK (creatinine phosphokinase) into the blood. High levels of CK in children can be a sign of DMD or another muscle disease.

- Genetic tests - Checking a sample of blood for the abnormal gene for DMD. 
- Muscle biopsy - A biopsy is a procedure to take a tiny sample of muscle to be examined under a microscope. A biopsy is only needed if the first genetic test returns with a negative result. This occurs in about one-third $(30 \%)$ of cases. The procedure is done in the clinic and takes about 20 minutes. The sample is usually taken from the thigh muscle (quadriceps). First the area is 'frozen' or numbed with a local anaesthetic. Then the doctor makes a tiny cut (incision) and removes a sample of muscle with a needle. The incision is closed with a stitch that will need to be removed in a few days.

How child get DMD: DMD is inherited. The abnormal gene for DMD is found on the $\mathrm{X}$ chromosome, passed down from the mother. In about $66 \%$ of the cases, the mother carries the disease causing gene in all the cells of the body (see below) and will need to be tested to see if she does carry the gene mutation. In about $33 \%$ of the cases, the mutation is only in the ovary (gremlin mosacism) or randomly occurs during the development of the embryo.

\section{Modern Treatment of DMD}

The health care team at the Neuromuscular and Neurometabolic Centre will recommend a treatment plan to meet your child's needs. The goals of treatment are to control symptoms, keep muscles working as long as possible and give your child the best possible quality of life. There is no cure for DMD.

- Physiotherapy - It is important for your child to be active. Using muscles helps them stay as strong as possible. Inactivity, such as bed rest, can cause the muscles to break down faster

- Corticosteroids - Steroid medications can slow the progress of the disorder. It is important to remember that side effects are possible with all medications.

Ayurvedic Management of DMD: Acharya's have mentioned specific chikitsa sootra for the condition by considering its severity and importance which can easily be understood by the Vaidyas ${ }^{(7)}$. Acharyas while explaining the dhatupaka avastha clearly signifies the importance of Agni which is whole and sole responsible for the formation of the next dhatus. Thus correction of agni should be done by administration of deepana and pachana dravyas in order to strengthen the process, doshas must be balanced and metabolic toxins must be eliminated from dhatus through panchakarma $^{(8)}$. The pre-operative process quoted by Acharyas has the concept of "Brhmanyastu mrudu langyet "that signifies the usage of Rukshana for better brihmana treatment modalities. ${ }^{(9)}$ for example udvartana which helps in the removal of srotorodha and does Sthiri karana of angas. Pachana medicines are also explained as a mode of Rukshana chikitsa and it is also must in the treatment of DMD initially with deepana, like parishekha with Dhanyamla ${ }^{(10-11)}$. Panchakarma the penta bio purifactory methods of Ayurveda i.e. Vamana, Virechana, Niruha, Anuvansan and Nasya are of prime importance. ${ }^{(12)}$ Vamana of mrudu kind i.e. using the drugs like madana phala which has anapaitava as guna, has least complications, if the person is present with kapha sthana gata pitta or utkilstha kapha lekhans as it pacifies the vitiated kapha but also corrects the depleted medas $^{(13-14)}$. Another set of data shows usage of vacha as dravya for the vamana which signifies major improvement in paediatrics age for the neuromuscular disorder ${ }^{(15)}$. Virechana Karma of mrudu in nature explained under Vatsya upkarma has anulomana property and tridoshahara property ${ }^{(16)}$. Thus, its repeated course is beneficial. 
Amritprasha ghrutha and Tikta ghrutas are used as shodhana snehapana. Research has shown that Virechana does the detoxification which lead to better absorption of Rasyana Drugs, other Bruhana Dravyas and correction of Agni. ${ }^{(17)}$ Basti is another variety of the Karma especially Bruhana variety of basti which clearly shows its efficacy in this condition for example usage of Mamsa rasa Basti and yapana basti (contains madhanaphala) with kala and karma format, considering the condition as gambhir dhatu gata vikara ${ }^{(18)}$. Tikta Ghruthas, Ashwanganadha ghrutha and Chagalayadi ghrutha can be administered as Anuvanasa basti ${ }^{(19-20)}$. It also rejuvenates the body and further helps in improving from the dhatukshaya caused due by the vata dosha that is why both virechana and basti are explained in the principle of Medomamsa dusti ${ }^{(21)}$. Nasya has less importance when we talk about genetic disorder however it is assumed that it can be used for the treatment of various associated symptoms like depression due to its mana prasdana action $^{(22)}$. After the purification Rasyana therapy can be adopted. Not only these invasive therapies like virechana, Basti etc, but upkarma i.e Para panchakarma procedures are very much essential for the same. It is very well understood in the treatment principle of Vataroga by Charaka and Yogaratnakar that upakarmas like Abhyanga, Swedana are having prime treatment modalities ${ }^{(23)}$. Snehana both bahya and abhyantra helps to pacifies the vata dosha ${ }^{(24)}$. In contrast Abhyanga a variety of bhaya sneha with oil like Balaashwagandhalakshadi taila, Mahanaryana Taila and Mahamamsadi taila helps in subsiding the vata dosha, improves the tonicity of the muscle and compacts the body ${ }^{(25-26)}$. Whereas swedana like Shastikashaali panda swedana also improves the tone of the body ${ }^{(27)}$. Swedana karma increases the metabolic activity which in turn increases the oxygen demand and blood flow. This vasodilatation stimulates the superficial nerve ending causing a reflex dilatation of the arterioles. Due to the effect of heat on the sensory nerve ending there will be a reflex stimulation of sweat glands in the areas exposed to heat. This rise in temperature induces muscle relaxation and increases the efficacy of muscle action as the increased blood supply ensures the optimum condition for the muscle contraction ${ }^{(28)}$. Swedana also acts by the mechanism of thermoregulation regulated by skin and coordinated with the functions of the other excretory organs. These Ayurvedic treatment used for the management of DMD.

\section{Conclusions}

Duchenne muscular dystrophy is a neuromuscular disorder There is no any satisfactory treatment for the DMD in other pathies except Ayurveda where as in Ayurveda have lots of description of etiopathology and management of mansagata drushti which can be co related with the DMD. This article is an attempt to highlighting on details of DMD and its Ayurvedic management.

\section{References}

[1] www.cdc.gov.in. (27 December 2018: 12.30 pm)

[2] Acharya Yadavaji Trikamaji’s Agnivesa, Charaka Samhita, with Chakrapaanidatta. In: ed Ayurved Dipika, Commentary. Reprint ed. New Delhi: Chaukhambha Surbharati Parkashan; 2008. p. 32122

[3] Agnivesa, Charaka Samhita, with Chakrapaanidatta. In: Acharya Yadavaji Trikamaji, ed Ayurved Dipika, Commentary. Reprint ed. Varanasi: Chaukhambha Orientalia; 2009. p. 617

[4] (C) Hamilton Health Sciences, 2008 PD 6284 01/2014WPC\PtEd\CH\DuchenneMuscularDystrophy-lw.doc dt/January 14, 2014 Duchenne muscular dystrophy (DMD) (27 December $2018: 12.30$ pm ) 
[5] Dennis L. Kasper et al. $19^{\text {th }}$ edition Harrison's manual of medicine chapter 163 osteoarthritis, p.1054

[6] Ronald B. David (2009), Clinical pediatric neurology, Ed. Demos Medical New York

[7] Shasthri K, Chaturvedi G. Charaka Samhita with Vidyotini Commentary. Edition, Varanasi: Chaukambha Bharati Academy; 2011 reprint. p. 793.

[8] Agnivesa, Charaka Samhita, with Chakrapaanidatta. In: Acharya YT, ed. Ayurved Dipika, Commentary. Reprint ed. Varanasi: Chaukhambha Orientalia; 2009. p. 620

[9] Vagbhata, Astanga Hridaya, with Arundatta. In: Kunte AM, ed. Sarvangasundari, Commentary. Reprint ed. Varanasi: Chaukhambha Orientalia; 2011. p. 225.

[10] Vagbhata, Astanga Hridaya, with Arundatta. In: Kunte AM, ed. Sarvangasundari, Commentary. Reprint ed. Varanasi: Chaukhambha Orientalia; 2011.p. 28

[11] Vagbhata, Astanga Hridaya, with Arundatta. In: Kunte AM, ed. Sarvangasundari, Commentary. Reprint ed. Varanasi: Chaukhambha Orientalia; 2011.p. 223

[12] Agnivesa, Charaka Samhita, with Chakrapaanidatta. In: Acharya Yadavaji Trikamaji, ed. Ayurved Dipika, Commentary. Reprint ed. Varanasi: Chaukhambha Orientalia ; 2011. p. 25

[13] Agnivesa, Charaka Samhita, with Chakrapaanidatta. In: Acharya YT, ed Ayurved Dipika, Commentary. Reprint ed. New Delhi: Chaukhambha Surbharati Parkashan; 2008. p. 88

[14] Agnivesa, Charaka Samhita, with Chakrapaanidatta. In: Acharya YT, ed. Ayurved Dipika, Commentary. Reprint ed. New Delhi: Chaukhambha Surbharati Parkashan; 2008. p. 651

[15] Mukherji P K et al. Acorus calamus: Scientific Validation of Ayurvedic Tradition from Natural Resources Pharmaceutical Biology, 2007;45(8): p.651-666

[16] Vagbhata, Astanga Hridaya, with Arundatta. In: Kunte AM, ed. Sarvangasundari, Commentary. Reprint ed. Varanasi: Chaukhambha Orientalia; 2011.p. 267

[17] Jain Mukesh D,Yoga Annapurna and Pandey MP 2002 Preliminary Study of Integrated Approach of Panch karma, Yoga and Ayurvedic Medicine in the Management of Muscular Dystrophy : 46 Patients. World Health Review,1:1,p. 33-35

[18] Agnivesa, Charaka Samhita, with Chakrapaanidatta. In: Acharya YT, ed. Ayurved Dipika, Commentary. Reprint ed. New Delhi: Chaukhambha Surbharati Parkashan ; 2008. p. 731-32

[19] Vagbhata, Astanga Hridaya, with Arundatta. In: Kunte AM, ed. Sarvangasundari, Commentary. Reprint ed. Varanasi: Chaukhambha Orientalia; 2011.p. 594

[20] Govind Das, Bhaisjya ratnavali, In: Ambika datta shastri,edi. vidyotini commentary, reprint ed. Varanasi: Chaukamba Sanskrit Sansthan; 2001.p. 301.

[21] Agnivesa, Charaka Samhita, with Chakrapaanidatta. In: Acharya YT, ed. Ayurved Dipika, Commentary. Reprint ed. New Delhi: Chaukhambha Surbharati Parkashan; 2008. p. 621

[22] Agnivesa, Charaka Samhita, with Chakrapaanidatta. In: Acharya YT, ed. Ayurved Dipika, Commentary. Reprint ed. New Delhi: Chaukhambha Surbharati Parkashan; 2008. p. 26

[23] Agnivesa, Charaka Samhita, with Chakrapaanidatta. In: Acharya YT, ed Ayurved Dipika, Commentary. Reprint ed. New Delhi: Chaukambha Surbharati Parkashan; 2008. p. 678

[24] Govind Das, Bhaisjya ratnavali, In: Ambika datta shastri, ed. vidyotini commentary.reprint ed. Varanasi: Chaukamba Sanskrit Sansthan; 2001.p. 396-97

[25] Chakara pani Datta,Chakra Datta, In: Jagdishvara prasad Tripathi, ed. Bhavarthsadipani fifth ed. Varanasi: Chaukamba Sanskrit series;1983.p. 199

[26] Agnivesa, Charaka Samhita, with Chakrapaanidatta. In: Acharya YT, ed Ayurved Dipika, Commentary. Reprint ed. New Delhi Chaukhambha Surbharati Parkashan; 2008. p. 90-91

[27] Agnivesa, Charaka Samhita, with Chakrapaanidatta. In: Acharya YT, ed. Ayurved Dipika, Commentary. Reprint ed. New Delhi: Chaukhambha Surbharati Parkashan; 2008. p. 89

[28] Martini FH. Fundamentals of Anatomy and Physiology chapter 5. 4th ed. New Jersey: Prentice Hall Inc. Simon \& Schuster; 1998. p. 148-155.

*Corresponding author.

E-mail address: akshaypatankar6@ gmail.com/rbr.226@ gmail.com 